\title{
PEMBERDAYAN MASYARAKAT MELALUI CREATION OF ENTERPRISES FORMATION OF ENTREPRENEURS (CEFE) SEBAGAI UPAYA MENGHADAPI DAMPAK EKONOMI AKIBAT ADANYA WABAH COVID 19
}

\author{
Neni Nurhayati \\ Program Studi Akuntansi, Universitas Kuningan, Indonesia \\ e-mail: neni.nurhayati@uniku.ac.id
}

\begin{abstract}
The purpose of this service is to train and provide entrepreneurial skills and assistance in stages for participants to have entrepreneurial and business competencies so that they are able to establish a viable business by taking advantage of existing opportunities and develop human resources who are able to create job opportunities for themselves and others who in the end will create a new source of income and even become the main source of income for the family as a measure to face the economic impact of the COVID-19 pandemic. The methods used in the implementation of community service are training using technical information presentation and simulation methods as well as mentoring with an individual approach by way of on the spot. The result of this community service activity is to create entrepreneurial skills which are used as alternative solutions to be able to create new sources of income and even become the main source of income for families amid the conditions of Covid-19.
\end{abstract}

Keywords: community empowerment, covid 19, entrepreneurship

\begin{abstract}
Abstrak
Tujuan pengabdian ini dilakukan untuk melatih dan memberikan keterampilan serta pendampingan kewirausahaan secara bertahap bagi peserta agar memiliki kompetensi kewirausahaan dan bisnis sehingga mampu mendirikan usaha yang layak dengan memanfaatkan peluang yang ada serta mengembangkan SDM yang mampu menciptakan kesempatan kerja bagi dirinya sendiri maupun orang lain yang pada akhirnya akan menciptakan sumber penghasilan baru bahkan menjadi sumber penghasilan utama keluarga sebagai langkah menghadapi dampak ekonomi adanya pandemi covid 19. Adapun metode yang digunakan dalam pelaksanaan pengabdian yaitu pelatihan dengan menggunakan teknis presentasi informasi dan metode simulasi serta pendampingan dengan pendekatan individual dengan cara on the spot. Hasil dari kegiatan pengabdian kepada masyarakat ini yaitu menciptakan keterampilan wirausaha yang dijadikan alternatif solusi untuk dapat menciptakan sumber penghasilan baru bahkan bisa menjadi sumber penghasilan utama keluarga ditengah kondisi covid-19 ini.
\end{abstract}

Kata Kunci: pemberdayaan masyarakat, covid 19, kewirausahaan

\section{PENDAHULUAN}

Desa Cikijing merupakan desa di wilayah Kecamatan Cikijing Kabupaten Majalengka. Secara umum desa Cikijing merupakan pusat kegiatan ekonomi di Kabupaten Majalengka dalam sektor perdagangan dan industri. Hal tersebut di dukung oleh letak geografis desa Cikiijing yang terbilang strategis yang letaknya berada pada segitiga emas yang dilalui untuk dapat melintasi Kabupaten Kuningan, Ciamis, dan Tasikmalaya. Desa Cikijing sangat strategis untuk berbagai macam perdagangan. Perekonomian yang menjadi andalan di Desa Cikijing ini adalah perdagangan. Desa ini memiliki tingkat ekonomi yang sangat tinggi. Namun dengan adanya musibah pandemi covid 19 telah banyak memberikan dampak pada berbagai elemen masyrakat, tidak terlepas bagi masyrakat Desa Cikijing Kabupaten Majalengka yang tentunya berdampak pada keadaan ekonomi keluarga. 
MOC atau kepanjangan dari Motor Ojeg Cikijing merupakan sebuah group gabungan dari para ojeg Cikijing. Secara umum adanya pandemi covid-19 ini dirasakan sangat berdampak pada seluruh kehidupan masyarakat tanpa terkecuali bagi kehidupan keluarga ojeg MOC. Dari hasil wawancara awal dengan anggota MOC di dapatkan informasi bahwa adanya pandemi covid 19 berdampak pada berbagai hal sebagai berikut: jumlah penumpang menurun, kesulitan dalam memenuhi kebutuhan hidup keluarga, kesulitan dalam membayar utang bulanan, Kesulitan dalam memenuhi setoran motor, ketidakharmonisan keluarga, istri tidak dapat berangkat ke luar negeri untuk menjadi TKW untuk sementara waktu, dan Tidak ada penghasilan sampingan selain mengandalkan dari usaha ojek pengkolan. Adanuya kondisi ini membuktikan bahwa musinbah covid 19 sangat berdampak pada anggota keluarga tersebut.

Permasalahan ini merupakan masalah yang umum terjadi di semua wilayah baik di Indonesia maupun di Luar Negeri karena musibah covid 19 merupakan masalah dunia yang saat ini memang menjadi isu utama. Hal ini ini bukan tidak bisa hanya di bebankan pada pemerintah saja tetapi menjadi sebuah keharusan bagi semua pihak untuk dengan penuh kesadaran untuk dapat membangkitkan roda perekonomian keluarga bahkan tentunya perekonomian secara nasional. Konsep Creation Of Enterprises Formation Of Entrepreneurs (Cefe) menjadi sebuah pilihan penting untuk dapat keluar dan menjawab tantangan problematika ekonomi saat ini. CEFE merupakan sebuah konsep dengan tujuan untuk melatih peserta secara bertahap agar memiliki kompetensi kewirausahaan dan bisnis, melatih wirausahawan agar mampu mendirikan usaha yang layak dengan memanfaatkan peluang yang ada pada saat tertentu dan di daerah tertentu, serta mengembangkan SDM yang mampu menciptakan kesempatan kerja bagi dirinya sendiri maupun orang lain sesuai tuntutan pembangunan.

Pilihan menjadi wirausaha sesungguhnya merupakan satu alternatif pilihan yang paling menjanjikan untuk kehidupan saat ini bahkan yang akan datang. Sayangnya pilihan menjadi wirausaha ini belum begitu banyak tumbuh dikalangan masyarakat luas begitupun di Desa Cikijing. Oleh karena itu pelatihan kewirausahaan harus terus dilakukan untuk siapapun yang peduli terhadap kesejahteraan masyarakat (Dharmawati: 2019:15) . Hal ini menjadi motivasi penulis untuk dapat memberikan sumbangsih pemikiran berupa Pemberdayan Masyarakat Melalui Creation Of Enterprises Formation Of Entrepreneurs (Cefe) Sebagai Langkah Menghadapi Dampak Ekonomi Adanya Covid 19. Adanya pelatihan dan pendampingan wirausaha ini disesuaikan pada minat, pengetahuan, dan fasilitas yang tersedia dari masingmasing keluarga anggota MOC. Dengan demikian diharapkan adanya pelatihan dan pendampingan keterampilan wirausaha bagi keluarga anggota MOC dapat menjadi alternatif sumber penghasilan keluarga yang nantinya dapat dijadikan penopang hidup keluarga di tengah kondisi pandemi covid 19 ini. Selain itu, adanya pelatihan dan pendampingan keterampilan wirausaha ini juga merupakan solusi tepat dalam menumbuhkebangkan UMKM di Indonesia.

Inilah momentum yang tepat untuk membangun mental masyarakat agar lebih kuat dan kompetitif. Kegiatan pengabdian ini ingin mentransferkan pengetahuan dan keterampilan kepada keluarga dari anggota ojeg MOC Cikijing terkait dengan kewirausahaan dengan memanfaatkan potensi sumber daya yang tersedia dalam membantu memenuhi kebutuhan hidup di masa pandemi covid-19 ini. Sehingga perlu adanya upaya untuk memotivasi dan merangsang anggota keluarga ojeg MOC melalui kegiatan sosialisasi maupun penyuluhan. Adanya kegiatan ini diharapkan dapat membantu keluarga anggota MOC memiliki usaha yang di kelola keluarga demi memenuhi kebutuhan hidup sehari hari.

Berdasarkan solusi yang ditawarkan diharapkan dapat merangsang keluarga anggota MOC agar lebih terampil dalam menerapkan dan menggali potensi diri serta tanggap terhadap 
peluang yang ada untuk berwirausaha sebagai jawaban atas dampak pandemi covid 19 yang terjadi sehingga keluarga anggota MOC ini memiliki sumber penghasilan baru disamping penghasilan utama. Selain itu, adanya pelatihan dan pendampingan kewirausahaan ini diharapkan dapat berkontribusi dalam memberikan pemahaman serta ilmu yang bermanfaat sehingga akan memunculkan UKM UKM baru yang dapat menopang perekonomian bangsa.

\section{METODE PELAKSANAAN}

Berdasarkan permasalahan yang sudah diidentifikasi dan dirumuskan di atas, maka metode pelaksanaan kegiatan yang digunakan dalam pengabdian ini menggunakan metode antara lain:

1. Pelatihan merupakan proses belajar mengajar dengan menggunakan teknik dan metode tertentu secara konsepsional dengan tujuan untuk meningkatkan keterampilan dan kemampuan seseorang atau sekelompok orang (Siagian dalam Lubis, 2008). Adapun teknik yang digunakan dalam metode pelatihan ini yaitu:

a. Teknik presentasi informasi yang meliputi ceramah dan diskusi

b. Metode simulasi yang meliputi studi kasus, permainan bisnis dan latihan proses pencatatan maupun pelaporan akuntansi keuangan masjid

2. Pendampingan dilakukan dengan pendekatan individual.

Adapun langkah-langkah kegiatan yang dilakukan adalah pelatihan dan pendampingan dengan cara on the spot ke kediaman keluarga ojek pengkolan MOC dengan tahapan sebagai berikut:

a. Sosialisasi mengenai konsep wirausaha

b. Mengkaji kompetensi pribadi peserta dalam situasi yang berubah dengan mentukan strategi yang sesuai.

c. Menilai suatu proyek/produk dalam kaitannya dengan kekuatan, kelemahan, peluang dan ancaman (SWOT Analysis)

d. Memvisualisasikan faktor-faktor yang mempengaruhi terhadap pasar ( harga, produk, distribusi dan promosi )

e. Mensimulasikan kewirausahaan dari suatu usaha manufaktur berskala kecil.

f. Membuat dan mengimplementasikan rencana usaha

g. Evaluasi

\section{HASIL DAN PEMBAHASAN}

Acara puncak Kegiatan Pengabdian kepada Mayarakat (PkM) telah dilakukan selama 3 (tiga) hari dimulai tanggal 9 sampai dengan tanggal 11 November 2020 yang terbagi menjadi beberapa sesi kegiatan. Untuk pelatihan dan pendampingan program CREATION OF ENTERPRISES FORMATION OF ENTREPRENEURS (CEFE) dilakukan pada tanggal 9 November 2020. Kegiatan pengabdian kepada masyarakat ini bertempat di Desa Cikijing Kecamatan Cikijing Kabupaten Majalengka Jawa Barat. Kegiatan tersebut berjalan lancar dan sesuai dengan yang telah ditargetkan sebelumnya. Antusiasme masyarakat terlihat begitu jelas dengan dibuktikan masyarakat yang hadir pada saat itu sebanyak 15 orang dari total 15 peserta yang diundang. Selama kegiatan berlangsung terlihat keaktifan dari masyarakat dalam merespon berbagai kajian yang kami bawakan baik itu menjawab pertanyaan atau mengajukan pertanyaan. Adapun langkah-langkah kegiatan yang dilakukan berupa pelatihan dan pendampingan keterampilan wirausaha yang bisa menjadi alternatif solusi untuk dapat menciptakan sumber penghasilan baru bahkan bisa menjadi sumber penghasilan utama keluarga. 
Peserta kegiatan ini didominasi oleh istri serta anak dari anggota MOC yang diharapkan adanya bentuk usaha baru yang dilakukan oleh istri maupun anak anggota MOC tersebut dapat membantu ekonomi keluarga disamping matapencaharian utama kepala keluarga adalah jasa ojeg pengkolan yang tergabung ke dalam kelompok MOC (Motor Ojeg Cikijing). Pelaksanaan pelatihan serta pendampingan awalnya dilakukan melalui metode on the spot ke rumah-rumah, namun dikarenakan alamat kediaman peserta satu dengan lainnya berdekatan maka pelatihan dan pendampingan juga dilakukan secara berbarengan di salah satu rumah peserta selama 3 hari secara bergantian dengan tetap menjaga protokol kesehatan. Khusus untuk kegiatan program CEFE ini dilakukan selama 1 (satu) hari di kediaman Ibu Ibu Ruki Blok Jumat.

Kegiatan PkM ini dilakukan dengan beberapa tahap yaitu : Tahap awal yang dilakukan adalah dengan mensosialisasikan konsep wirausaha kepada para peserta. Pada tahapan ini peserta diberikan materi terkait konsep kewirausahaan, bagaimana memunculkan ide, membangun kreativitas, memotivasi, serta membaca peluang usaha. Adanya bencana covid-19 memaksa kita untuk lebih kreatif dan pandai membaca peluang agar keadaan ekonomi keluarga tetap aman. Pada tahapan ini peserta diberikan beberapa materi yang dijelaskan melalui ppt dengan metode ceramah. Pada pertemuan pertama ini juga peserta diberikan tugas untuk mencari dan mengenali potensi diri serta menuangkannya dalam bentuk kreatifitas dengan tetap berpatokan pada peluang usaha yang ada. Peserta kegiatan ini sebagian besar belum memiliki usaha, namun ada beberapa peserta yang sudah memiliki usaha kecil yang baru saja buka pada saat adanya wabah covid 19 maupun sudah buka sebelumnya sebelum wabah covid 19 terjadi. Kegiatan pertama ini dilakukan di kediaman Ibu Ruki Blok Jumat Desa Cikijing Majalengka. Kegiatan ini diawali pada pukul 09.00 wib sampai dengan pukul 14.00 wib.

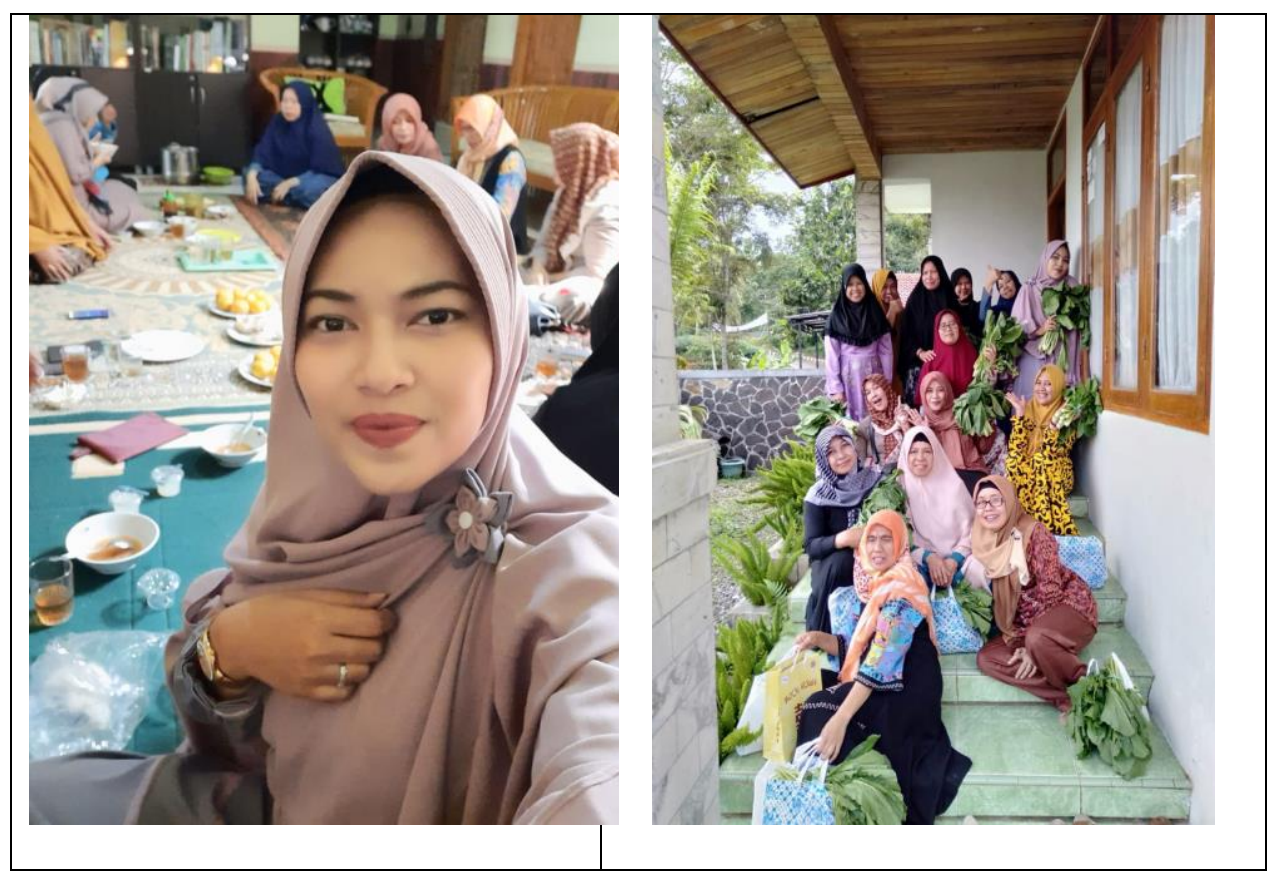

Gambar 1. Kegiatan di Kediaman Ibu Ruki Blok Jumat

Pada kegiatan inipun dikaji terkait dengan kompetensi pribadi masing masing peserta, baik itu kompetensi di bidang usaha jasa, pembuatan produk, dan lain sebagainya. Peserta diberikan kesempatan untuk menganalisis kemampuan pribadinya dalam bidang kewirausahaan. 
Sehingga pada tahapan ini peserta akan mampu untuk merencanakan kegiatan usaha yang akan dilakukan berdasarkan pada kompetensi yang dimiliki dengan tetap berpedoman pada peluang usaha yang ada. Selanjutnya, menilai suatu proyek/produk dalam kaitannya dengan kekuatan, kelemahan, peluang dan ancaman (SWOT Analysis). Pada tahapan ini, setelah pada kegiatan awal peserta diberikan pilihan untuk memilih usaha sesuai dengan peluang dan kompetensi nya masing masing maka pada tahapan ini peserta diberikan sebuah kajian untuk menganalisis kekuatan, kelemahan, peluang dan ancaman dari usaha yang sudah mereka tentuka sebelumnya. Peserta diberikan kesempatan untuk menganalisis apa saja kekuatan yang dimiliki untuk menjalankan usaha yang dipilih, kelemahan yang dimiliki untuk menjalankan usaha yang dipilih, menganalisis peluang yang ada dari usaha yang dipilih juga tentunya menganalisis ancaman ancaman apa saja yang akan di hadapi ketika menjalankan usaha tersebut. Hal ini dilakukan agar peserta mampu mengenali rencana usaha nya masing-masing dan mencari strategi terbaik dari setiap ancaman serta hambatan yang ada dengan memaksimalkan kekuatan serta peluang yang ada pada usahanya tersebut.

Setelah para peserta mampu untuk menilai kekuatan, kelemahan, peluang dan ancaman dari pilihan usahanya, maka langkah selanjutnya peserta diberikan sebuah kajian terkait dengan memvisualisasikan faktor-faktor yang mempengaruhi terhadap pasar ( harga, produk, distribusi dan promosi ). Pada tahapan ini peserta ditugaskan untuk dapat menganalisis produk usahanya terkait dengan penetapan harga, rencana produk, pendistribusian, serta promosi apa saja yang akan dilakukan untuk dapat mengenalkan produk usahanya tersebut kepada masyarakat secara luas. Peserta diberikan kesempatan untuk mengonsep kira kira produk yang dihasilkan akan didistribusikan ke mana saja serta kegaitan apasaja yang akan dilakukan untuk dapat memperkenalkan produk tersebut ke masayarakat luas. Setelah tahapan demi tahapan diatas dilalui, tahapan selanjutnya adalah mensimulasikan kewirausahaan dari suatu usaha manufaktur berskala kecil. Peserta diberikan sebuah tugas untuk mensimulasikan produk usahanya baik dari penjelasan berupa ide, motivasi, peluang serta analisis SWOT yang sudah di kaji sebelumnya. Pada tahapan ini peserta mensimulasikan bagaimana sebuah produk usahnya tersebut dapat tercipta bahkan sampai terwujud menjadi sebuah alternatif usaha yang akan dilakukan. Pada tahapan ini ditujukan agar peserta benar benar mampu memptraktekan ilmu yang sudah diperoleh sehingga para peserta memiliki gambaran yang sangat jelas mengenai usaha yang akan dilakukan nya.

Pada tahapan selanjutnya yaitu membuat dan mengimplementasikan rencana usaha. Pada tahapan ini peserta diberikan sebuah format isian berupa formulir usulan rencana usaha. Pada tahapan ini diharapkan peserta akan semakin jelas dan terukur bentuk usaha yang akan mereka jalankan. Form isian tersebut akan sangat membantu peserta dalam menganalisis setiap faktor faktor yang menjadi pertimbangan bahkan menjadi aspek penting dalam membuat sebuah bisnis baru atau mungkin pengembangan usaha yang telah ada sebelumnya. Adanya renana usaha yang telah di kaji, di analisis, dan si isi oleh para peserta, maka tahapan selanjutnya adalah evaluasi dari setiap rencana bisnis yang telah di pilih oleh para pesreta. Tahapan evaluasi ini membantu peserta untuk lebih memantapkan rencana usaha nya. Dalam tahapan ini juga dikaji apakah rencana usaha tersebut benar benar dapat terealisasi atau tidak. Tahapan ini lebih bersifat diskusi untuk saling bertukar pikiran dan memberikan saran terbaik atas usaha yang direncanakan masing-masing peserta. 
Gambar 2. Slide Paparan Materi CEFE

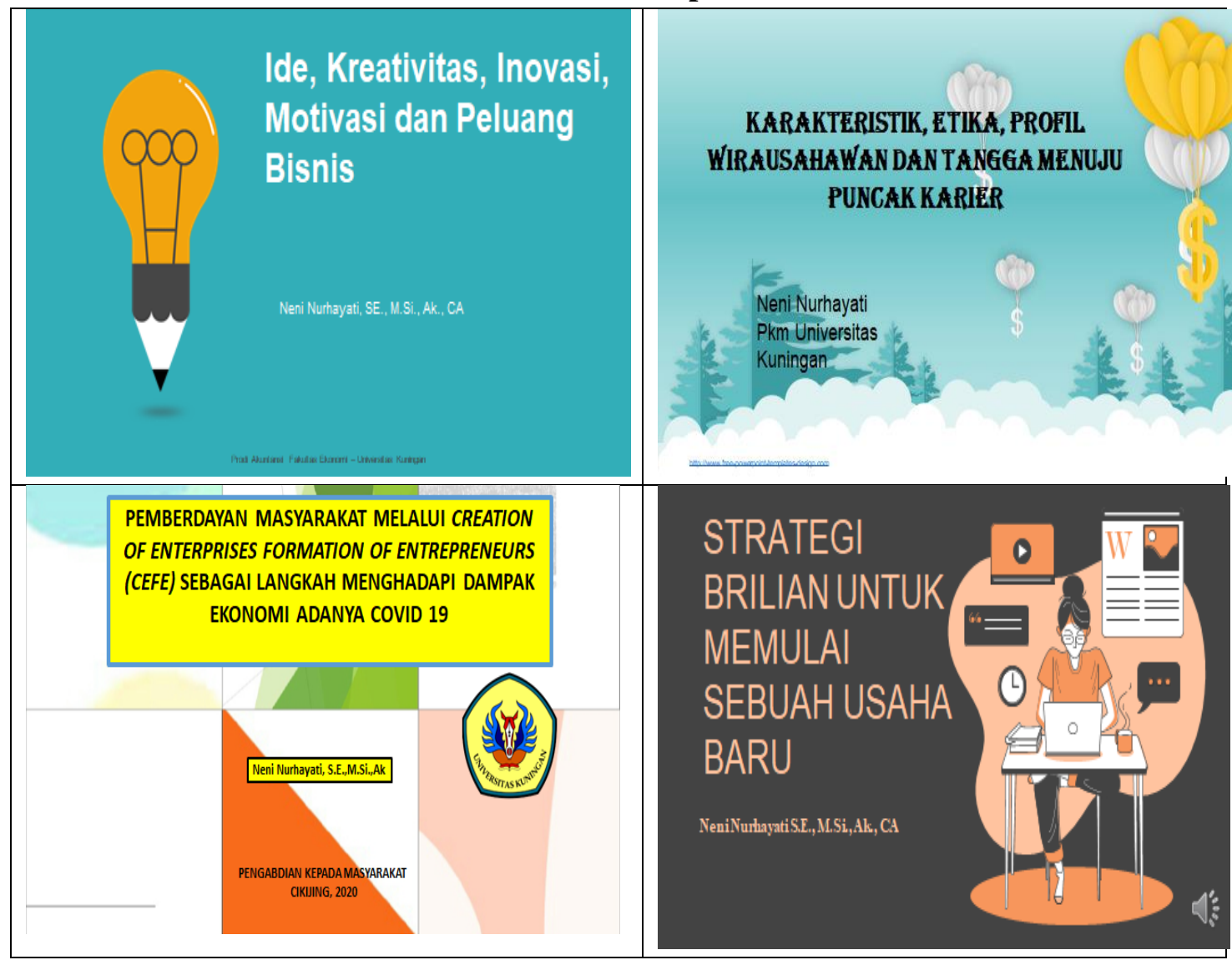

SIMPULAN

Pelaksanaan kegiatan Pemberdayan Masyarakat Melalui Creation Of Enterprises Formation Of Entrepreneurs (Cefe) Sebagai Langkah Menghadapi Dampak Ekonomi Adanya Covid 19 (Studi Kasus Pada Keluarga Anggota MOC Desa Cikijing Majalengka) berjalan dengan kondusif sesuai dengan tujuan. Hal ini terlihat dari dukungan dan antusias peserta dalam mengikuti setiap tahapan tahapan kegiatan sehingga peserta dapat memperoleh keterampilan wirausaha yang bisa menjadi alternatif solusi untuk dapat menciptakan sumber penghasilan baru bahkan bisa menjadi sumber penghasilan utama keluarga dengan menghasilkan sebuah produk yang bernilai tambah untuk dijadikan sebuah komoditas ditengah kondisi pandemi covid 19 saat ini.

\section{SARAN}

Pelaksanaan kegiatan Pemberdayan Masyarakat Melalui Creation Of Enterprises Formation Of Entrepreneurs (Cefe) Sebagai Langkah Menghadapi Dampak Ekonomi Adanya Covid 19 perlu dilakukan kepada mitra lain yang tidak hanya berdomisili di Desa Cikijing saja tetapi pada seluruh warga masyarakat di desa lain agar mampu menciptakan sumber penghasilan baru bahkan bisa menjadi sumber penghasilan utama keluarga dengan menghasilkan sebuah produk yang bernilai tambah untuk dijadikan sebuah komoditas ditengah kondisi pandemi covid 19 saat ini. Hal ini juga dijadikan sebuah upaya agar terciptanya desa mandiri yang memiliki OVOP masing masing sehingga setiap desa mampu meningkatkan 
kesejahteraan keluarga dengan berwirausaha mengembangakan potensi desanya masingmasing.

\section{UCAPAN TERIMA KASIH}

Penulis ucapkan terimakasih kepada seluruh pihak LPPM Universitas Kuningan, Pimpinan Universitas Kuningan beserta jajarannya) yang telah membantu terlaksananya kegiatan pengabdian kepada masyarakat ini.

\section{DAFTAR PUSTAKA}

Alma Buchari.2018. Kewirausahaan untuk mahasiswa dan umum. Bandung: Alfabeta.

Anak Suryo, (2007). Akuntansi Untuk UKM, Metode akuntansi Praktis dan sederhana untuk Usaha Kecil dan Menengah, Media Pressindo.D Made Dharmawati. 2016. Kewirausahaan. Jakarta: PT. Raja Grafindo

Iqbal Arraniri. Strategi Bisnis Usaha Pastel Mini Desa Tenjolayar Kecamatan Pancalang Kabupaten Kuningan Jawa Barat. Empowerment : Jurnal Pengabdian Masyarakat. Vol.02 Nomor 02. 2019.48-59

Kasmir. Kewirausahaan. PT. Raja Grafindo Perkasa. Jakarta

LPPM. 2020. Panduan Pengabdian Kepada Masyarakat. Universitas Kuningan

Rusdiana.2013. Kewirausahaan Teori \& Praktik. Bandung: Pustaka Setia.

Sukirno, Sadono. 2006. Ekonomi Pembangunan Edisi Kedua. Kencana. Jakarta

Suwari Akhmaddhian, et.al. Bantuan Hukum Bagi Pelaku Usaha Kecil Dan Menengah Di Kecamatan Selajambe, Kuningan. Empowerment : Jurnal Pengabdian Masyarakat. Vol.02 Nomor 02. 2019.67-73

Wennekers, Sander, and Roy Thurik. 1999. Linking Entrepreneurship and Economic Growth. Small Business Economics. 